\title{
COMPARISON OF NUTRITION STATUS OF CHILDREN WITH AGED 1-2 YEARS IN COASTAL AND URBAN AREAS
}

\author{
Agus Purnamasari \\ Midwifery Program, Faculty of Health, Universitas Borneo Tarakan
}

\begin{abstract}
Background: Stunting, a chronic malnutrition of children, remains a global health concern. In Indonesia, around 37\% (almost 9 million) of children under five are stunted. The difference in the prevalence of stunting in coastal and urban areas needs attention for the comprehensive handling of stunting. This study aimed to analyze the comparison of nutritional status in coastal and urban areas for toddlers aged 1-2 years.

Subjects and Method: This was a cross-sectional study conducted at coastal and urban areas, Tarakan, North Kalimantan from October to November 2016. A total of 94 toddlers aged 1-2 years was selected by total sampling. The dependent variables were dietary intake and nutritional status. The independent variables were living in coastal and urban areas. The data were collected using questionnaires. The data were analyzed by independent t-test.

Results: Mean of nutritional status of toddlers in urban area was higher (Mean= $4.24 ; \mathrm{SD}=$ 1.27) than in coastal area (Mean=-3.17; $\mathrm{SD}=1.14)$, and it was statistically significant $(\mathrm{p}=0.002)$. There was no significant difference in dietary intake of toddlers between coastal and urban areas.

Conclusion: There is significant difference of nutritional status in toddlers aged 1-2 years between coastal and urban areas.
\end{abstract}

Keywords: nutritional status, dietary intake, coastal, urban, toddlers

\section{Correspondence:}

Agus Purnamasari. Midwifery Program, Faculty of Health, Universitas Borneo Tarakan. Jl. Amal Lama No.1 Tarakan, North Kalimantan. Email: aguspurnamasari@gmail.com. Mobile: +628214399469 . 